\title{
A COMPARATIVE STUDY OF BACTERIAL COMMUNITIES DETERMINED BY CULTURE- DEPENDENT AND-INDEPENDENT APPROACHES IN OIL PALM PLANTED ON TROPICAL PEATLAND
}

\author{
AYOB, ZAHIDAH ${ }^{\star}$ and KUSAI, NOR AZIZAH*
}

\begin{abstract}
A combination of deoxyribonucleic acid (DNA)-based method and sequencing technologies have initiated a new era of soil microbial ecology to examine the patterns of bacterial communities in tropical peatland. The aims of the study are to verify and compare the bacterial communities in a 12-year-old oil palm plantation on peat of Sibu, Sarawak, Malaysia using culture-dependent and culture-independent approaches. The bacterial diversity identified from both approaches were amplified using 165 ribosomal deoxyribonucleic acid ( $r D N A$ ) (341/907) primer, sequenced and analysed. This resulted in recovering a total of 227 bacterial isolates belonging to four major phyla accumulated from 22 genera. Meanwhile, about 216 denaturing gradient gel electrophoresis (DGGE) bands were excised, which corresponded to 195 different bacterial species from 20 different phyla by culture-independent method. Although both approaches detected a total of four predominant bacterial phyla (Proteobacteria, Firmicutes, Actinobacteria and Bacteroidetes), in general, different taxonomic sequences were targeted by each method. In comparison to culture-dependent, polymerase chain reaction (PCR)-DGGE method identified a higher rate of bacterial diversity and richness and also detected non-culturable bacteria. Thus, this suggests that culture-independent method was showed to be more efficient on the bacterial diversity identification that will lead towards unravelling the hidden bacterial species associated with agricultural practices carried out in Southeast Asia peatland.
\end{abstract}

Keywords: tropical peatland, oil palm plantation, 16S rDNA, culture-dependent, polymerase chain reaction-denaturing gradient gel electrophoresis (PCR-DGGE).

Received: 28 September 2020; Accepted: 4 January 2021; Published online: 26 February 2021.

\section{INTRODUCTION}

Prokaryotes are the most abundant group of soil microorganisms, which include bacteria and archaea and play fundamental ecological roles in the decomposition, biogeochemical cycling and maintenance of soil structure, soil quality, and

Malaysian Palm Oil Board,

6 Persiaran Institusi, Bandar Baru Bangi,

43000 Kajang, Selangor, Malaysia.

E-mail: zahidahayob@mpob.gov.my fertility of tropical peatland (Schneider et al., 2015; Nurulita et al., 2016). Previous studies have reported that many factors, including land-use change such as peat swamp forest conversion to oil palm plantation, plant species, and soil properties drive changes in the $\mathrm{pH}$, temperature, water content, organic carbon content, nutrient content and soil texture, which influence the diversity of soil microbial communities (Kerfahi et al., 2014; Schneider et al., 2015; Wu et al., 2015; Nurulita et al., 2016). Furthermore, understanding the diversity of soil microbial communities is vital for knowing their function in 
ecosystems and the impact of oil palm management practices and plant communities (Kerfahiet al., 2014). Thus, the identification of bacterial communities in deep peat cultivated with oil palm using culturedependent and culture-independent approaches would postulate the impact of these communities on environmental changes in the tropical peatland.

The 16S ribosomal deoxyribonucleic acid (16S rDNA) gene is used as a universal molecular marker in microbial diversity studies because it has highly conserved regions that display considerable sequence variations, even within closely related taxa (Singh et al., 2011). The diversity of bacterial communities from peat ecosystems can be determined using various approaches, most commonly culture-dependent methods such as spread-plate (Roslan et al., 2015; Kusai and Ayob, 2020) and culture-independent methods, namely denaturing gradient gel electrophoresis (DGGE) (Jackson et al., 2009; Arai et al., 2014; Maidin et al., 2016; Nurulita et al., 2016), terminal restriction fragment length polymorphism (T-RFLP) (Situmorang et al., 2016), 454-pyrosequencing (Kanokratana et al., 2011; Liu et al., 2020), and nextgeneration sequencing (Tripathi et al., 2016; Too et al., 2018). Among these approaches, DGGE is one of the most well-established and isused toexplain microbial diversity studies by comparing the composition, richness and structure of the microbial communities in soil, other environments (Ellis et al., 2003; Singh et al., 2012; Piterina and Pembroke, 2013; Nagendran et al., 2014; Teo and Wong, 2014; Maidin et al., 2016; Nurulita et al., 2016) and food samples (Chen et al., 2008; Jianzhong et al., 2009; Miguel et al., 2010; Kesmen and Kacmaz, 2011). This novel method was introduced into microbial ecology in 1993 by Muyzer et al.

Traditionally, culture-based methods provide limited information on microbial communities because the majority of bacteria are difficult to culture in a laboratory since they require specific growth media and, as a result, a large proportion of microbial communities remain unexplored. Previous studies have reported that culture-dependent methods present copiotrophs and high guanine-cytosine (GC) gram-positive bacteria because these bacterial groups are capable of growing on selective media (Smit et al., 2001; Edenborn and Sexstone, 2007), whereas culture-independent methods may detect bacteria that are difficult to culture, such as those from the phyla Acidobacteria and Verrucomicrobia (Lipson and Schmidt, 2004; Edenborn and Sexstone, 2007). Advancements in culture-independent methods have facilitated microbial diversity studies by comparing the composition and richness of the bacterial communities in soil (Qaisrani et al., 2019). In addition, culture-independent methods such as DGGE has the capacity to process multiple samples rapidly by analysing bands that migrate separately on DGGE gels, and enables the detection of diverse members of soil microbial organisms, including unculturable microbes that are unable to proliferate in culture media (Watanabe et al., 2004; Green et al., 2010; Chaudhary et al., 2019). Nevertheless, the culture-dependent method is still essential for isolating and defining the taxonomic and metabolites of pure strains, and also understanding how their functions influence bacterial diversity patterns in tropical peatland (González-Rocha et al., 2017; Chaudhary et al., 2019).

Very few studies have reported on the diversity of bacterial communities in Southeast Asia peatland. Previously, analysis of the bacterial community composition of tropical peatland was based separately on culturable or cultureindependent methods and compared different ecosystems (Maidin et al., 2016; Nurulita et al., 2016; Tripathi et al., 2016; Too et al., 2018; Dhandapani et al., 2019; Kusai and Ayob, 2020; Liu et al., 2020). No data is available and this study intends to highlight the comparison between the bacterial community composition of culture-dependent and cultureindependent approaches of bacterial communities from a 12-year-old oil palm plantation on tropical peatland. Therefore, in this article, we investigate the application of these approaches to verify and compare bacterial communities in isolation on growth media, followed by $16 \mathrm{~S}$ rRNA-based identification of isolates, whereas the cultureindependent method involved extracting DNA directly from the soil for polymerase chain reaction (PCR) amplification of the 16S rRNA gene followed by DGGE analysis and sequencing.

\section{MATERIALS AND METHODS}

\section{Peat Sampling}

Peat was sampled in an oil palm (Elaeis guineensis Jacq.) plantation located in the vicinity of Sibu, Sarawak, Malaysia. Muriate of potash (MOP) $\left(0.75 \mathrm{~kg} \mathrm{palm}^{-1}\right)$, urea $\left[\mathrm{CO}\left(\mathrm{NH}_{2}\right)_{2}\right]\left(0.25 \mathrm{~kg} \mathrm{palm}^{-1}\right)$ and rock phosphate (RP) $\left(0.2 \mathrm{~kg} \mathrm{palm}^{-1}\right)$ have been supplemented to the 12-year-old oil palms. The studied site was classified as undecomposed sapric organic materials based on Malaysian Unified Classification of Organic Soils (MUCOS) by Paramananthan (2016). This type of soil consists of sapric material of $1 / 3$ fibre content and no wood up to $100 \mathrm{~cm}$ depth (Veloo et al., 2015). The average annual rainfall over the area was estimated at $2624.38 \mathrm{~mm} \mathrm{yr}^{-1}$ during year 2013. Sampling was carried out during dry season with less than $100 \mathrm{~mm}$ precipitation on August 2013. Peat samples were collected at 10 sampling points (N1-N10) with depth between $0-30 \mathrm{~cm}$, using peat auger. The sampling points were at least $10 \mathrm{~m}$ apart from each other with 
the central point at $2^{\circ} 09^{\prime} 47.065^{\prime \prime} \mathrm{N}, 111^{\circ} 55^{\prime} 22.387^{\prime \prime} \mathrm{E}$ (Kusai et al., 2018). Peat samples were chilled in the ice box during transportation from the field to the laboratory and stored at $4^{\circ} \mathrm{C}$ until further analysis. The inorganic elements including macronutrients, micronutrient and heavy metal contents were analysed using Perkin Elmer ELAN DRC-e ICPMass Spectrometry (Perkin Elmer Sdn Bhd, Petaling Jaya, Selangor, Malaysia). The moisture content and $\mathrm{pH}$ of peat samples were also analysed (Ayob et al., 2018).

\section{Culture-Dependent Method}

Isolation of bacteria. Approximately, $1 \mathrm{~g}$ of peat was suspended in $9 \mathrm{ml}$ of sterile deionised water and homogenised by orbital shaker at $150 \mathrm{rpm}$ for $2 \mathrm{hr}$. An aliquot of $100 \mu \mathrm{l}$ of $10^{-8}$ and $10^{-9}$ dilutions of each sample was spread on seven culture media: Nutrient agar (NA) (Davis et al., 2005), soil enrichment medium (EM) (Germida and de Freitas, 2007), actinomycetes medium (ACT) (Porter et al., 1960), anaerobic medium (AN) (Holland, 1987), nitrogendeficient medium (N) (Rennie, 1981), pikovskaya medium (P) (Vazquez et al., 2000) and aleksandrov medium (K) (Hu et al., 2006). Triplicates of spread plates were incubated at $30^{\circ} \mathrm{C}$ for three days. The total number of colony forming units (CFU) plates were calculated and expressed as the concentration of CFU per $1 \mathrm{~g}$ of peat sample. Different colonies were selected based on colony morphology (shape, structure, colour, pattern, size) (Nath et al., 2018) and sub-cultured on the respective media for seven days to obtain pure cultures. After that, the selected colonies from pure cultures were picked and dipped into $100 \mu \mathrm{l}$ of sterile deionised water, heat-shocked for $45 \mathrm{sec}$, and centrifuged for $2 \mathrm{~min}$ at $10000 \times \mathrm{g}$ (Dashti et al., 2009). The bacterial supernatant was kept at $-20^{\circ} \mathrm{C}$ prior to PCR amplification. Then, the pure cultures were maintained in glycerol stock at $-80^{\circ} \mathrm{C}$

DNA amplification. Pure isolated DNA was subjected to amplification of the target V3 to $\mathrm{V} 5$ regions located in the $16 \mathrm{~S}$ rRNA gene by PCR using the barcoding primers; 341-F 5'-CCTACGGGAGGCAGCAG-3' and 907-R 5'-CCCCGTCAATTCATTTGAGTTT-3' (Muyzer et al., 1993; 1995). The PCR reaction mixture using GoTaq ${ }^{\circledR}$ DNA polymerase (Promega Corporation, Washington, USA) with the final $25 \mu \mathrm{l}$ volume containing 1.25 units of PCR buffer, $2.5 \mathrm{mM}$ magnesium chloride $\left(\mathrm{MgCl}_{2}\right), 0.3 \%$ bovine serum albumin (BSA), $0.5 \mathrm{mM}$ of each deoxynucleotide triphosphate (dNTP), $0.4 \mu \mathrm{M}$ of each primer, 1.25 units of Taq polymerase, $5 \mu \mathrm{l}$ of bacterial supernatant was used as a template for PCR amplification. The PCR amplification was performed with an Eppendorf Mastercycler $\AA$ nexus (Medigene Sdn
Bhd, Puchong, Selangor, Malaysia). The following thermal cycling scheme was used for amplification of $16 \mathrm{~S}$ rDNA: initial hot start incubation at $94^{\circ} \mathrm{C}$ for $2 \mathrm{~min}, 35$ cycles of denaturation at $94^{\circ} \mathrm{C}$ for $30 \mathrm{sec}$, annealing for $30 \mathrm{sec}$ at $52^{\circ} \mathrm{C}$, extension at $72^{\circ} \mathrm{C}$ for $30 \mathrm{sec}$, followed by a final extension period at $72^{\circ} \mathrm{C}$ for $2 \mathrm{~min}$. Deionised water was used as template for negative control. The PCR products were analysed by electrophoresis in $1 \%(\mathrm{w} / \mathrm{v})$ agarose gels. Gels were stained with $0.1 \%(\mathrm{v} / \mathrm{v})$ SYBR® Safe DNA gel stain and visualised with an Alpha Imager HP system (Alpha Innotech, San Leandro, CA, USA).

\section{Culture-Independent Method}

DNA extraction. Peat DNA was extracted using GeneMATRIX Soil DNA Purification Kit (EURx Ltd, Gdansk, Poland) according to the manufacturer's instructions. The concentration and quality of the extracted DNA was determined using a NanoPhotometer® P360 (Implen GmbH, Schatzbogen, Germany). The DNA was stored at $-20^{\circ} \mathrm{C}$ prior to PCR amplification.

PCR-DGGE analysis. The 16S rRNA gene was amplified by PCR with the target V3 to V5 regions for DGGE analysis using the 341-F 5'-CGCCCGCCGCGCGCGGCGGGCGGGGCGG GGGCACGGGGGGCCTACGGGAGGCAGCAG-3’ primer which added 40-bp GC-rich sequence (GCclamp) in the $5^{\prime}$ primer to obtain a stable melting point of the DNA fragments in the DGGE and 907R 5'-CCCCGTCAATTCATTTGAGTTT-3' (Muyzer et al., 1993; 1995). A $25 \mu \mathrm{l}$ PCR reaction mixture contained $250 \mathrm{ng}$ of extracted peat DNA as a template and the PCR amplification conditions were performed following the same protocol as described earlier in the 'DNA amplification' subsection.

DGGE was performed using the Dcode ${ }^{\mathrm{TM}}$ universal mutation detection system (Bio-Rad, USA) according to the manufacturer's instructions. A $20 \mu \mathrm{l}$ PCR products mixed with $6 \mu \mathrm{l}$ green loading dye (Promega, Madison, Wisconsin, USA) were loaded onto polyacrylamide gels in $1 \times$ TAE (TrisAcetate-EDTA) running buffer. Polyacrylamide gels were made with a denaturing gradient where $100 \%$ of denaturant contained $7 \mathrm{M}$ urea (Sigma-Aldrich, St. Louis, Missouri, USA) and 40\% (v/v) deionised formamide (Amresco ${ }^{\circledR}$, Solon, Ohio, USA). The polyacrylamide gels (37.5:1, acrylamide: Bisacrylamide) in a gradient used was $40 \%-70 \%$ and running for $17 \mathrm{hr}$ at $60^{\circ} \mathrm{C}$ and $70 \mathrm{~V}$ (Maidin et al., 2016). After electrophoresis, the gels were stained for $1 \mathrm{hr}$ in $1 \times$ TAE with $0.1 \%(\mathrm{v} / \mathrm{v})$ SYBR ${ }^{\circledR}$ Safe DNA gel stain and visualised with ultraviolet (UV) transilluminator using under Alpha Imager HP system (Alpha Innotech, San Leandro, CA, USA). DGGE bands with high intensity and dominant were excised, resuspended in $50 \mu \mathrm{TE}$ buffer and 
incubated overnight at $4^{\circ} \mathrm{C}$. Eluted DNA was used as a template for re-amplification of 16S rDNA gene using universal primers, 341F (with no GC-clamp) and 907R (Muyzer et al., 1993) according to protocol as described in the 'DNA amplification' subsection.

DGGE banding patterns analysis. DGGE banding patterns were analysed using CLIQS 1D Pro software (TotalLab Ltd, Newcastle, United Kingdom). Dendrogram of bacterial diversity was constructed using the unweighted pair group with arithmetic mean (UPGMA) and the similarities among DGGE bands were measured using Dice coefficient index. The Shannon-Wiener index $\left(\mathrm{H}^{\prime}\right)$ was calculated to determine species diversity in a community (Shannon and Weaver, 1949) species richness was used to measure of the relative abundance of different bacterial species (Hill, 1973).

DNA purification and sequencing. The positive gel$550 \mathrm{bp}$ band size of the PCR products from bacterial supernatant and eluted DNA from excised DGGE gels were purified using the EasyPure ${ }^{\circledR}$ Quick Gel Extraction Kit (TransGen Biotech, Beijing, China) and sent for Sanger sequencing using services provided by First BASE Laboratories Sdn Bhd (Seri Kembangan, Selangor, Malaysia). The $16 \mathrm{~S}$ rDNA gene sequences obtained were analysed by using basic local alignment search tool (BLAST) (www. ncbi.nlm.nih.gov/Blast) to identify the nearest relative of bacterial sequenced in the National Centre for Biotechnology Information (NCBI) GenBank database.

\section{Statistical Analysis}

The analyses of physico-chemical characteristics of the peat samples and total counts were conducted in triplicate and the data obtained were analysed using SPSS for Windows software (SPSS 16.0 for Windows Evaluation Version software, SPSS Inc., USA). The normality of the data was analysed using the Shapiro-Wilk test. The data were analysed using One-way analysis of variance (ANOVA) with post-hoc multiple comparisons, i.e., Duncan test for normal data and Kruskal-Wallis test for non-normal data. Differences were considered to be significant if the probability $P<0.05$ (Pallant, 2007).

\section{RESULTS AND DISCUSSION}

\section{Physico-chemical Peat Characteristics}

The physico-chemical properties and element concentrations of oil palm-cultivated peatland are shown in Tables 1 and 2. The soil moisture proportion was high and this was in agreement with peat swamp conditions under water-logged conditions and with oxygen deficiency (Page and Baird, 2016; Tripathi et al., 2016). Overall, the peat $\mathrm{pH}$ was highly acidic; it was suggested that the cause of this lower $\mathrm{pH}$ value was fertiliser leaching during a high monthly rainfall on the site studied (Nurulita et al., 2016). In addition, a low $\mathrm{pH}$ would affect root development and availability of nutrients such as macronutrients ( $\mathrm{N}$ and $\mathrm{K}$ ) and micronutrients $(\mathrm{Cu}, \mathrm{Zn}$ and $\mathrm{B})$ on the oil palm plantation (Parish et al., 2012). Research by Fierer and Jackson (2006) reported that soil $\mathrm{pH}$ was a better predictor of both bacterial richness and diversity, with the lowest levels in acidic soils. This is in contrast to a previous study by Tripathi et al. (2016), which stated that Acidobacteria was higher in peat swamp forest and negatively correlated with the soil low $\mathrm{pH}$. The average peat temperature was low $\left(24^{\circ} \mathrm{C}\right)$, possibly due to the canopy cover from vegetation fronds, which hinder the sun from heating the soil surface. This was contradictory to previous studies where the peat temperature exceeded $28^{\circ} \mathrm{C}$ (Posa et al., 2011). In fact, oil palm can adapt to acidic and humid conditions ranging from $24^{\circ} \mathrm{C}-30^{\circ} \mathrm{C}$ in tropical ecosystems with appropriate management practices (Sheil et al., 2009). In this study, high carbon (C) and low nitrogen $(\mathrm{N})$ in the oil palm plantation indicated low decomposition and mineralisation rates, which was consistent with Ayob et al. (2018) and Kusai et al. (2018), who found low decomposition rates in oil palm plantations but at different study sites in Sarawak, Malaysia. Despite nutrient deficiency in peat soil, large quantities of nutrients are required by oil palm to support their vegetative growth and fruit production. Peatland is nutrient-poor and has a high water-holding capacity; therefore, oil palm has to maintain or increase their nutrient storage capacity in order to provide nutrients for palm growth (Bah and Rahman, 2004). Among the elements in peat, iron ( $\mathrm{Fe}$ ) content was the highest compared to others and this was in accordance with the findings of Schneider et al. (2015). Meanwhile, calcium (Ca) was the second-highest element; this might be due to supplementation of urea in the oil palm plantation, a finding which is supported by Bah and Rahman (2004). Moreover, the deficiency of potassium $(\mathrm{K})$, copper $(\mathrm{Cu})$, zinc $(\mathrm{Zn})$, and boron (B) in peatland cultivated with oil palm might be influenced by peat type and water availability (Melling, 2016). This was also supported by Fierer and Jackson (2006), who mentioned that vegetation type, carbon availability, nutrient availability and soil moisture may contribute to variations in the microbial community composition across ecosystems. Therefore, proper management practices in oil palm plantations, such as fertiliser application during the rainy season, are important for optimising fertiliser efficiency for oil palm growth on peat (Parish et al., 2012). 
TABLE 1. PHYSICO-CHEMICAL PEAT CHARACTERISTICS IN THE 12-YEAR-OLD OIL PALM PLANTATION

\begin{tabular}{lcccccc}
\hline Ecosystem & $\begin{array}{c}\text { Moisture } \\
\text { proportion (\%) }\end{array}$ & $\mathrm{pH}$ & Temperature & Total C (\%) & Total N (\%) & C/N quotient \\
\hline 12 YOP & $72 \pm 0.7$ & $3.9 \pm 0.05$ & $24.1 \pm 0.2$ & $59 \pm 0.3$ & $2.0 \pm 0.02$ & $29 \pm 0.2$ \\
\hline
\end{tabular}

Note: Data are presented as mean \pm standard error of mean (SEM). YOP - years old palm; C - carbon; N - nitrogen.

TABLE 2. ELEMENT CONCENTRATIONS $\left(\mathrm{mg} \mathrm{kg}^{-1}\right)$ OF PEAT SOIL IN THE 12-YEAR-OLD OIL PALM PLANTATION

\begin{tabular}{|c|c|c|c|c|c|c|c|c|c|c|c|c|}
\hline $\begin{array}{l}\text { Element } \\
\left(\mathrm{mg} \mathrm{kg}^{-1}\right)\end{array}$ & Mg & $\mathrm{Fe}$ & B & $\mathrm{Ca}$ & $\mathbf{P}$ & $\mathrm{Cr}$ & Mn & $\mathrm{Ni}$ & $\mathrm{Cu}$ & $\mathrm{Zn}$ & Mo & $\mathrm{Cd}$ \\
\hline 12 YOP & $200 \pm 9$ & $1000 \pm 100$ & $5 \pm 0.3$ & $800 \pm 40$ & $300 \pm 20$ & $4 \pm 0.2$ & $8 \pm 0.6$ & $2 \pm 0.1$ & $20 \pm 3$ & $20 \pm 1$ & 0.1 & 0.5 \\
\hline
\end{tabular}

Note: Data are presented as mean \pm standard error of mean (SEM). ' 0 ' digits in italics are not significant but indicate the position of decimal point. YOP - years old palm; Mg - magnesium; Fe - iron; B - boron; Ca - calcium; P - phosphorus; $\mathrm{Cr}$ - chromium; Mn - manganese; $\mathrm{Ni}$ - nickel; $\mathrm{Cu}$ - copper; $\mathrm{Zn}$ - zinc; Mo - molybdenum; Cd - cadmium; $\mathrm{Pb}$ - lead; K - potassium.

\section{Enumeration of the Bacterial Abundance}

The presence of microorganisms in the environmental samples, mainly in soil, could be estimated using the plate count method, an efficient method which approximates the number of cells present in the sample (Sutton, 2011). One gram of soil contains approximately $10^{5}-10^{8}$ bacteria (Abedon, 2011). The data in Figure 1 shows that a higher abundance of bacteria was detected in the AN with $(4.6 \pm 1.2) \times 10^{9} \mathrm{CFU} \mathrm{g}^{-1}$ and a lower prevalence was accumulated in the $\mathrm{ACT}$ with $(3.3 \pm 1.05) \times 10^{7} \mathrm{CFU} \mathrm{g}^{-1}$. The bacterial counts in $\mathrm{AN}$ were significantly different $(P<0.05)$ among other media and this was attributed to the dominant copiotrophic bacteria, whose distinctive feature is their ability to grow in high nutrient concentrations (Olsen and Bakken, 1987; Fuhrman et al., 2015). In the present study, a lower abundance of bacteria was detected in the ACT medium probably due to the slow growth rate of actinomycetes and this may mean specific media, incubation time and temperature and growth conditions are required (El Karkouri et al., 2019). This concurs with Ghazali et al. (2016) who reported that a higher number of actinomycetes isolates was found in a combination of culture media containing M1 medium, peat agar and oatmeal agar, and also in pre-heat treatment of peat soils. Meanwhile, the Pikovskaya $(\mathrm{P})$ medium showed a high abundance of bacterial counts among nitrogen, phosphorus and potassium (NPK) media. This suggests that phosphate-solubilising bacteria was abundant in the peat soil and these bacteria solubilise phosphate in the form of fertiliser, making it available for crop growth (Ruangsanka, 2014).

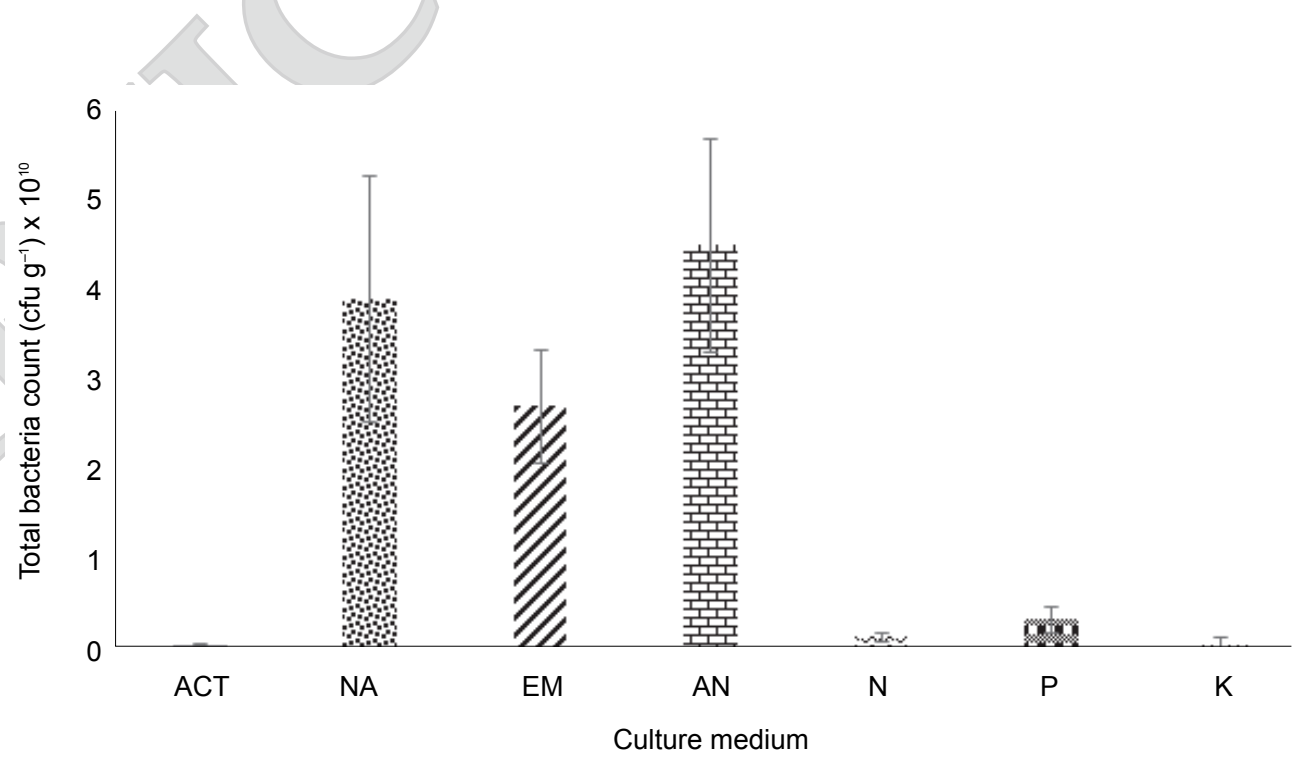

Note: ACT - actinomycetes medium; NA - nutrient agar; EM - enrichment medium; AN - anaerobic medium; N - nitrogen-deficient medium; P - pikovskaya medium; K - aleksandrov medium. 
Comparison of Bacterial Diversity Identified by Culture-Dependent and Culture-Independent Approaches

Soil prokaryotic communities are highly heterogeneous and important to the functioning of the terrestrial ecosystem, mainly in tropical peat swamp ecosystems (Tripathi et al., 2016). The present study on bacterial diversity using both culturedependent and culture-independent approaches frequently observed bacterial phyla in peat soil ecosystems, including Acidobacteria, Actinobacteria, Bacteroidetes, Firmicutes and Proteobacteria. The combination of classical bacterial enumeration in various culture media and molecular approaches led to the identification of 227 isolated bacterial strains, resulting in a total of 55 different species (Table 3). The most predominant class among the bacterial isolates was Betaproteobacteria (104, $45 \%)$, followed by Bacilli (90,40\%). The remaining prevalent classes were Gammaproteobacteria $(13,5 \%)$, Flavobacteria $(8,4 \%)$, Actinobacteria (6, 3\%), and Alphaproteobacteria (6, 3\%) (Figure 2). Nonetheless, the PCR-DGGE approach with a direct amplification of the 16S rDNA gene detected 216 bands and 195 different bacterial species in the studied site (Table 4). The PCR-DGGE analysis permitted the identification of 20 phyla, 30 classes, and 95 genera of bacteria. Unclassified bacteria $(73 \%)$ was the most dominant group in the studied site, followed by the predominant phyla Proteobacteria (11\%), Acidobacteria (9\%), Firmicutes (4\%), Bacteroidetes (1\%), Actinobacteria $(1 \%)$ and Synergistetes $(1 \%)$, as shown in Figure 3. The Shannon-Wiener biodiversity index for each approach was significantly different $(P<0.05)$ with culture-independent recording more diversity at $7.83 \pm 0.11$ (Table 4) while culture-dependent saw less diversity at $5.31 \pm 0.07$ (Table 3 ).

A dendrogram constructed using CLIQS 1D Pro software was used to examine the similarity of the bacterial communities based on the presence or absence of bands with the Dice coefficient index (Figure 4). An unweighted pair group method with arithmetic mean (UPGMA) analysis revealed four clusters. N9 and N2 had the highest similarity (83\%), where both were clustered together. N4 and N3 $(82 \%)$ and $\mathrm{N} 6$ and $\mathrm{N} 1(80 \%)$ were clustered together. N5 and N8 were closely clustered together between N3 and N4, and N9 and N2, respectively. The remaining samples from N10 and N7 were relatively different from others with less than $60 \%$ similarity. The bacterial profiles in the oil palm plantation seem to be related in all samples and this is in agreement with previous research by Teo and Wong (2014), who suggested that samples sequence with a higher similarity and which are clustered together might have a relatively higher chance of sharing the same bacterial taxa.
The overall findings showed a discrepancy between the bacterial diversity detected using the culture-dependent and culture-independent approaches. A large proportion of the bacterial groups of unclassified bacteria was detected using the culture-independent approach. Previous studies have suggested that they are novel or unique microorganisms in tropical peat soils that have not been well characterised microbiologically (Vincent, 2000; Stewart, 2012; Bottos et al., 2014). According to Miguel et al. (2010), this could happen due to multiple banding patterns attributed to sequence heterogeneity between multiple copies of $16 \mathrm{~S}$ rDNA strains. In addition, the phyla Acidobacteria was detected in peat soil using the culture-independent method but not with the culture-dependent method (Figure 3). Acidobacteria was dominant in Boreal and Sphagnum peat (Pankratov et al., 2008; Tsitko et al., 2014). Our finding was consistent with previous studies which reported that Acidobacteria was underrepresented in isolation cultures and indicates richness in the acidic conditions (Fierer et al., 2007; Shade et al., 2012; Sun et al., 2014). There were also similar patterns for phyla Candidatus Cloacimonetes, Chlorobi, Chloroflexi, Crenarchaeota, Cyanobacteria, DeinococcusThermus, Dictyoglomi, Euryarchaeota, Fibrobacteres, Fusibacteria, Plantomycetes, Spirochaetes, Synergistetes, Tenericutes and Thermotogae, which could not be assessed by the culture-dependent method in the present study (Table 4). Meanwhile, the isolation of soil bacteria represented four phyla (Actinobacteria, Bacteroidetes, Firmicutes and Proteobacteria) and three Proteobacteria classes consisting of Alpha-, Beta- and Gammaproteobacteria (Figure 2), findings similar to the studies by Fierer et al. (2007); Too et al. (2018); Kusai and Ayob (2020).

The results suggested that the soil bacterial phyla associated with copiotrophs were favourable for the culture-dependent method. These findings were supported by previous studies which reported that copiotrophic bacteria had higher growth rates, greater variability in population size and lower substrates affinities and were abundant in nutrientrich soils compared to oligotrophic bacteria (Fierer et al., 2007; Shade et al., 2012; Tripathi et al., 2016). For instance, carbon (C) mineralisation rate was a strong predictor of abundance in three groups in the ecosystem which were Acidobacteria, Proteobacteria and Bacteroidetes (Fierer et al., 2007). Previous studies also reported that bacteria belonging to the phylum Acidobacteria were present under oligotrophic conditions with very low resource availability (low $\mathrm{C}$ mineralisation rates) and were frequently associated with peat soils that are low labile C (Shade et al., 2012; Troxler et al., 2012; Sun et al., 2014). The findings were in accordance with those reported by Ding et al. (2013), which revealed a 
TABLE 3. LIST OF BACTERIAL ISOLATES IDENTIFIED FROM 12-YEAR-OLD OIL PALM PLANTATION AND AMPLIFIED USING CULTURE-DEPENDENT APPROACH, IN EACH CASE SHOWING THE SPECIES AND NCBI ACCESSION NUMBER OF THE CLOSEST MATCH IN THE GENBANK DATABASE

\begin{tabular}{|c|c|c|c|}
\hline Phylum class & Species & Accession no. & No. of isolates ( $\%$ of isolates) \\
\hline \multirow[t]{4}{*}{ Actinobacteria } & Micrococcus sp. & KP301109 & $1(0.4)$ \\
\hline & Mycobacterium abscessus & KP736045 & $1(0.4)$ \\
\hline & Sinomonas atrocyanea & LN890256 & $2(0.9)$ \\
\hline & Sinomonas flava & KR262446 & $2(0.9)$ \\
\hline \multirow[t]{2}{*}{ Bacteroidetes } & Elizabethkingia miricola & EU375848 & $6(2.6)$ \\
\hline & Flavobacteriaceae bacterium & KF619446 & $2(0.9)$ \\
\hline \multicolumn{4}{|l|}{ Firmicutes } \\
\hline \multirow[t]{15}{*}{ Bacilli } & Bacillus methylotrophicus & KT228265 & $2(0.9)$ \\
\hline & Bacillus mycoides & KY029076 & $2(0.9)$ \\
\hline & Bacillus pumilus & KX453891 & $3(1.3)$ \\
\hline & Bacillus safensis & HG424435 & $1(0.4)$ \\
\hline & Bacillus sp. & JX155391 & $1(0.4)$ \\
\hline & Bacillus subtilis & KX453903 & $23(10.0)$ \\
\hline & Bacillus tequilensis & KF157960 & $1(0.4)$ \\
\hline & Bacillus thuringiensis & KT783488 & $4(1.7)$ \\
\hline & Bacillus velezensis & KU752876 & $4(1.7)$ \\
\hline & Exiguobacterium acetylicum & KX458037 & $1(0.4)$ \\
\hline & Staphylococcus cohnii & KU550180 & $1(0.4)$ \\
\hline & Staphylococcus devriesei & КТ907081 & $1(0.4)$ \\
\hline & Staphylococcus haemolyticus & KM603641 & $2(0.9)$ \\
\hline & Staphylococcus hominis & KP780178 & $1(0.4)$ \\
\hline & Staphylococcus sp. & КР003995 & $1(0.4)$ \\
\hline \multicolumn{4}{|l|}{ Proteobacteria } \\
\hline \multirow[t]{3}{*}{ Alphaproteobacteria } & Ochrobactrum ciceri & KX185944 & $3(1.3)$ \\
\hline & Ochrobactrum intermedium & KX832724 & $2(0.9)$ \\
\hline & Rhodospirillum rubrum & JQ045832 & $1(0.4)$ \\
\hline \multirow[t]{14}{*}{ Betaproteobacteria } & Achromobacter denitrificans & KU180430 & $2(0.9)$ \\
\hline & Achromobacter insolitus & KJ620851 & $1(0.4)$ \\
\hline & Achromobacter sp. & KU534306 & $1(0.4)$ \\
\hline & Achromobacter xylosoxidans & KT429636 & $21(9.1)$ \\
\hline & Burkholderia cenocepacia & HМ042678 & $2(0.9)$ \\
\hline & Burkholderia diazotrophica & KT390896 & $1(0.4)$ \\
\hline & Burkholderia gladioli & JF431410 & $1(0.4)$ \\
\hline & Burkholderia lata & KX397363 & $12(5.2)$ \\
\hline & Burkholderia seminalis & KX066828 & $1(0.4)$ \\
\hline & Massilia sp. & JQ660175 & $2(0.9)$ \\
\hline & Ralstonia insidiosa & KT720194 & $41(17.8)$ \\
\hline & Ralstonia solanacearum & KX146476 & $14(6.1)$ \\
\hline & Ralstonia sp. & KF264453 & $4(1.7)$ \\
\hline & Thermothrix thiopara & U61284 & $1(0.4)$ \\
\hline \multirow[t]{12}{*}{ Gammaproteobacteria } & Acinetobacter calcoaceticus & KX781153 & $3(1.3)$ \\
\hline & Acinetobacter radioresistens & HE588005 & $1(0.4)$ \\
\hline & Dyella sp. & JQ864383 & $1(0.4)$ \\
\hline & Enterobacter hormaechei & KM878729 & $1(0.4)$ \\
\hline & Erwinia sp. & KM021124 & $1(0.4)$ \\
\hline & Pantoea calida & LC192167 & $3(1.3)$ \\
\hline & Pseudomonas stutzeri & KU921576 & $1(0.4)$ \\
\hline & Rahnella aquatilis & AM268331 & $1(0.4)$ \\
\hline & Stenotrophomonas maltophilia & AF390080 & $1(0.4)$ \\
\hline & Total isolates & & $227(100)$ \\
\hline & Species richness & & 51 \\
\hline & Shannon-wiener Index (H') & & $5.31 \pm 0.07$ \\
\hline
\end{tabular}

Note: NCBI -National Centre for Biotechnology Information. 


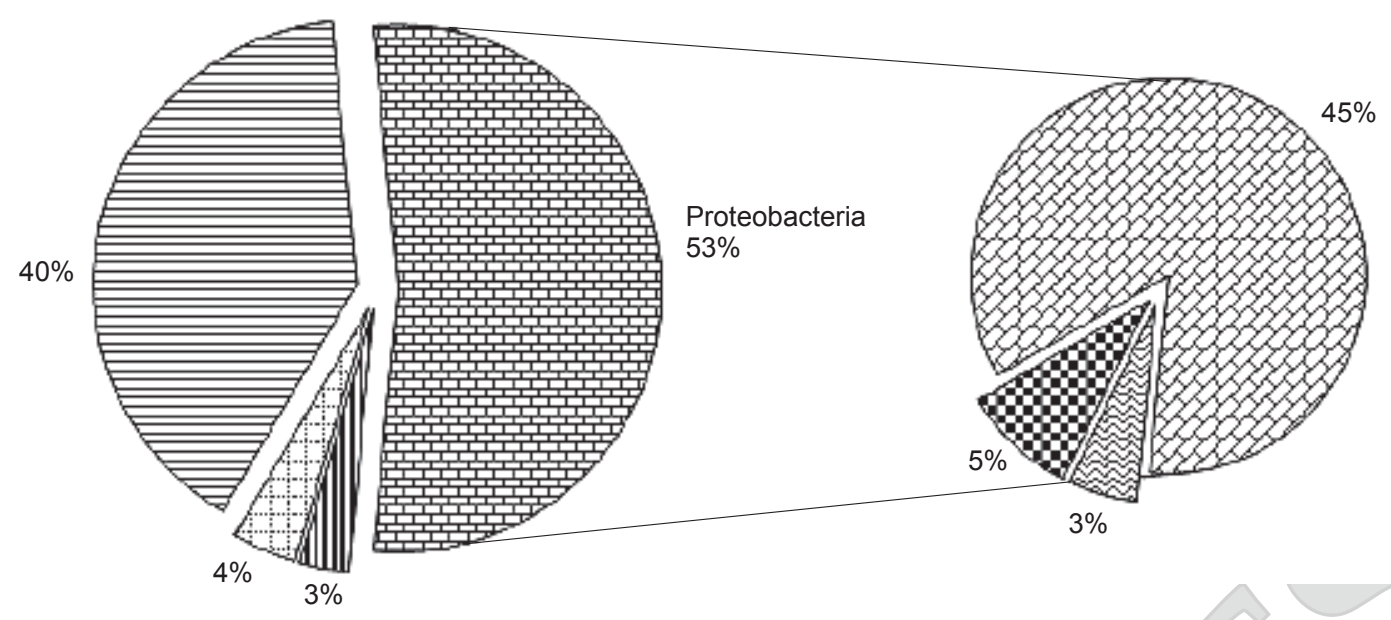
III Actinobacteria
Bacteroidetes
曰 Firmicutes
$\Xi$ Alpha
B Gamma
$\bigotimes$ Beta

Figure 2. Composition of bacterial phyla in the 12-year-old oil palm plantation identified by culture-dependent approach.

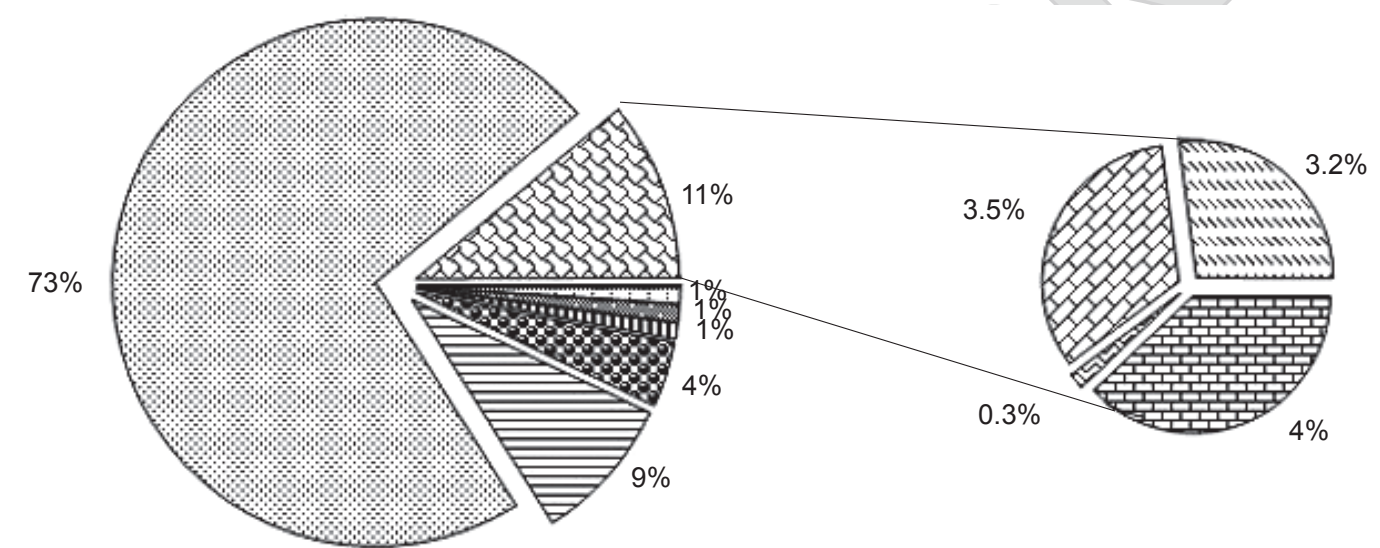

: Bacteroidetes

Firmicutes

凤 Proteobacteria

Bd Alpha

Synergistetes
曰 Acidobacteria
$\square$ Beta
$\square$ Gamma

ه Gamma

\section{Actinobacteria}

$\because$ Unclassified bacteria

$\square$ Delta

Figure 3. Composition of bacterial phyla in the 12-year-old oil palm plantation identified by culture-independent approach.
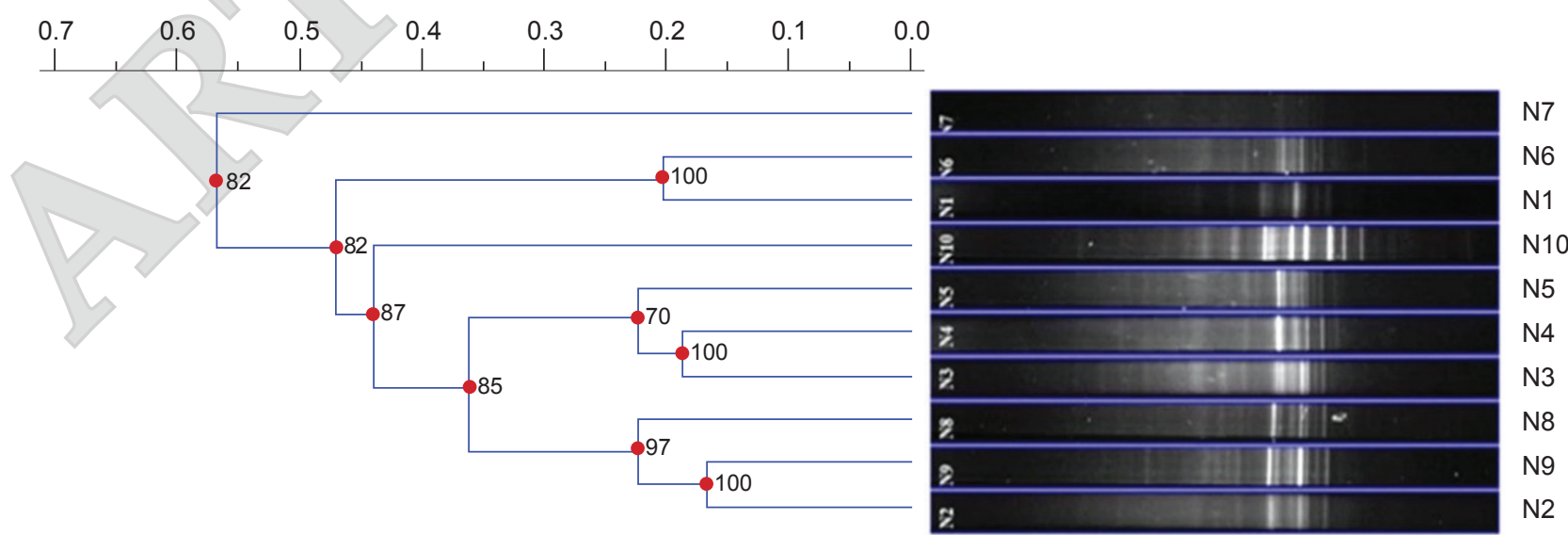

Figure 4. Dendrogram constructed by Dice coefficient index and clustering using unweighted pair group method with arithmetic mean (UPGMA) of bacterial communities based on $16 S$ ribosomal deoxyribonucleic acid (rDNA) denaturing gradient gel electrophoresis (DGGE) profiles of 12-year-old oil palm plantation using CLIQS 1D Pro software. 
TABLE 4. LIST OF BACTERIAL SPECIES IDENTIFIED FROM 12-YEAR- OLD OIL PALM PLANTATION AND AMPLIFIED USING PCR-DGGE METHOD, IN EACH CASE SHOWING THE SPECIES AND NCBI ACCESSION NUMBER OF THE CLOSEST MATCH IN THE GENBANK DATABASE

\begin{tabular}{|c|c|c|c|}
\hline Phylum class & Species & Accession no. & No. of species (\% of sp.) \\
\hline \multicolumn{4}{|l|}{ Acidobacteria } \\
\hline \multirow[t]{7}{*}{ Acidobacteriia } & U. Acidobacterium sp. & DQ991279 & $2(0.06)$ \\
\hline & U. Candidatus Koribacter sp. & KF225992 & $4(0.13)$ \\
\hline & U. Edaphobacter sp. & KR853545 & $2(0.6)$ \\
\hline & Granulicella tundricola & СР002480 & $1(0.03)$ \\
\hline & Occallatibacter savannae & HQ995661 & $1(0.03)$ \\
\hline & U. Acidobacteriaceae bacterium & FJ475538 & $5(0.16)$ \\
\hline & U. Acidobacteriales bacterium & AY395324 & $5(0.16)$ \\
\hline \multirow[t]{3}{*}{ Solibacteres } & U. Solibacter sp. & JQ177609 & $1(0.03)$ \\
\hline & Acidobacteria bacterium & KC485312 & $1(0.03)$ \\
\hline & U. Acidobacteria bacterium & FJ568777 & $252(8.19)$ \\
\hline \multicolumn{4}{|l|}{ Actinobacteria } \\
\hline \multirow[t]{13}{*}{ Actinobacteria } & Arthrobacter sp. & JX627624 & $1(0.03)$ \\
\hline & Mycobacterium tuberculosis & СР010968 & $1(0.03)$ \\
\hline & Mycobacterium vanbaalenii & СР000511 & $1(0.03)$ \\
\hline & Mycobacterium sp. & AJ783967 & $1(0.03)$ \\
\hline & Rhodococcus erythropolis & СР003761 & $1(0.03)$ \\
\hline & Rhodococcus sp. & СР012749 & $1(0.03)$ \\
\hline & U. Sporichthya sp. & GU000261 & $1(0.03)$ \\
\hline & Streptomyces albulus & СР006871 & $1(0.03)$ \\
\hline & Streptomyces sp. & СР013142 & $1(0.03)$ \\
\hline & U. Streptomyces sp. & GU000289 & $1(0.03)$ \\
\hline & Thermobifida fusca & СР000088 & $1(0.03)$ \\
\hline & U. actinomycete & JQ177968 & $3(0.09)$ \\
\hline & U. actinobacterium & JF947533 & $12(0.4)$ \\
\hline \multicolumn{4}{|l|}{ Bacteroidetes } \\
\hline Bacteroidia & Bacteroides ovatus & СР012938 & $2(0.06)$ \\
\hline Cytophagia & Cyclobacterium amurskyense & СР012040 & $1(0.03)$ \\
\hline \multirow[t]{2}{*}{ Flavobacteriia } & Chryseobacterium sp. & СР015199 & $1(0.03)$ \\
\hline & Maribacter sp. & СР002157 & $1(0.03)$ \\
\hline \multicolumn{4}{|c|}{ Candidatus Cloacimonetes } \\
\hline & Candidatus Cloacamonas acidaminovorans & CU466930 & $1(0.03)$ \\
\hline \multicolumn{4}{|l|}{ Chlorobi } \\
\hline & U. Chlorobi bacterium & FR733768 & $1(0.03)$ \\
\hline Chloroflexi & 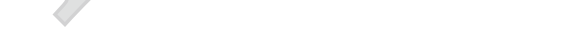 & & \\
\hline Ardenticatenia & Ardenticatena sp. & LN890655 & $1(0.03)$ \\
\hline \multicolumn{4}{|l|}{ Chloroflexi } \\
\hline Chloroflexia & U. Chloroflexales bacterium & AY694645 & $1(0.03)$ \\
\hline \multicolumn{4}{|l|}{ Crenarchaeota } \\
\hline & Ignisphaera aggregans & СР002098 & $1(0.03)$ \\
\hline \multicolumn{4}{|l|}{ Cyanobacteria } \\
\hline & Anabaena sp. & СР011456 & $1(0.03)$ \\
\hline 2 & Arthrospira sp. & FO818640 & $1(0.03)$ \\
\hline & Calothrix sp. & СР011382 & $1(0.03)$ \\
\hline & Cyanothece sp. & СР002198 & $1(0.03)$ \\
\hline & Rivularia sp. & СР003549 & $1(0.03)$ \\
\hline \multicolumn{4}{|c|}{ Deinococcus-Thermus } \\
\hline Thermoprotei & U. Thermus/ Deinococcus group bacterium & KC602722 & $1(0.03)$ \\
\hline \multicolumn{4}{|l|}{ Dictyoglomi } \\
\hline Dictyoglomia & Dictyoglomus turgidum & СР001251 & $1(0.03)$ \\
\hline
\end{tabular}


TABLE 4. LIST OF BACTERIAL SPECIES IDENTIFIED FROM 12-YEAR- OLD OIL PALM PLANTATION AND AMPLIFIED USING PCR-DGGE METHOD, IN EACH CASE SHOWING THE SPECIES AND NCBI ACCESSION NUMBER OF THE CLOSEST MATCH IN THE GENBANK DATABASE (continued)

\begin{tabular}{|c|c|c|c|}
\hline Phylum class & Species & Accession no. & No. of species ( $\%$ of sp.) \\
\hline \multicolumn{4}{|l|}{ Euryarchaeota } \\
\hline Halobacteria & U. Halobacteriales archaeon & LN796011 & $1(0.03)$ \\
\hline \multirow[t]{2}{*}{ Methanobacteria } & Methanosphaera stadtmanae & СР000102 & $1(0.03)$ \\
\hline & Methanobrevibacter olleyae & CP014265 & $1(0.03)$ \\
\hline Thermococci & Thermococcus nautili & CP007264 & $1(0.03)$ \\
\hline \multicolumn{4}{|l|}{ Fibrobacteres } \\
\hline \multirow{2}{*}{ Chitinivibrionia } & U. Chitinivibrionia bacterium & AB255984 & $2(0.06)$ \\
\hline & U. Fibrobacteres bacterium & KX368223 & $3(0.09)$ \\
\hline \multicolumn{4}{|l|}{ Firmicutes } \\
\hline \multirow[t]{15}{*}{ Bacilli } & Bacillus megaterium & СР010586 & $1(0.03)$ \\
\hline & Bacillus cereus biovar anthracis & СР001746 & $1(0.03)$ \\
\hline & Bacillus sp. & AB012934 & $1(0.03)$ \\
\hline & Bacillus cereus & LN559100 & $1(0.03)$ \\
\hline & Bacillus pumilus & KC831584 & $1(0.03)$ \\
\hline & Lactobacillus reuteri & СР000705 & $8(0.26)$ \\
\hline & U. Psychrobacillus sp. & LC050330 & $1(0.03)$ \\
\hline & Sporosarcina globispora & JX627616 & $1(0.03)$ \\
\hline & Sporosarcina psychrophila & СР014616 & $1(0.03)$ \\
\hline & Staphylococcus simulans & СР014016 & $1(0.03)$ \\
\hline & Staphylococcus warneri & HG799952 & $1(0.03)$ \\
\hline & Staphylococcus agnetis & СР009623 & $7(0.23)$ \\
\hline & $\begin{array}{l}\text { Staphylococcus saprophyticus subsp. } \\
\text { saprophyticus }\end{array}$ & HG799960 & $1(0.03)$ \\
\hline & Streptococcus intermedius & СР012718 & $1(0.03)$ \\
\hline & Streptococcus suis & СР002465 & $1(0.03)$ \\
\hline \multirow[t]{14}{*}{ Clostridia } & Clostridioides difficile & AM180355 & $15(0.5)$ \\
\hline & Clostridium saccharobutylicum & СР006721 & $1(0.03)$ \\
\hline & Clostridium beijerinckii & СР006777 & $3(0.09)$ \\
\hline & Clostridium botulinum & СР006908 & $4(0.13)$ \\
\hline & Clostridium pasteurianum & СР009268 & $2(0.06)$ \\
\hline & Clostridium perfringens & СР010993 & $1(0.03)$ \\
\hline & Desulfotomaculum kuznetsovii & CP002770 & $1(0.03)$ \\
\hline & Halobacteroides halobius & СР003359 & $1(0.03)$ \\
\hline & Ruminiclostridium sp. & СР015400 & $1(0.03)$ \\
\hline & Thermoanaerobacter wiegelii & СР002991 & $1(0.03)$ \\
\hline & Thermoanaerobacterium saccharolyticum & СР003184 & $1(0.03)$ \\
\hline & Clostridium propionicum & СР014223 & $1(0.03)$ \\
\hline & Anaerococcus prevotii & CP001708 & $1(0.03)$ \\
\hline & U. Firmicutes bacterium & EU043585 & $56(1.82)$ \\
\hline \multicolumn{4}{|l|}{ Fusobacteria } \\
\hline \multirow{2}{*}{ Fusobacteriia } & Fusobacterium hwasookii & СР013331 & $3(0.09)$ \\
\hline & Leptotrichia sp. & СР014231 & $1(0.03)$ \\
\hline \multicolumn{4}{|l|}{ Planctomycetes } \\
\hline Planctomycetia & U. Planctomycetales bacterium & JQ919020 & $8(0.26)$ \\
\hline \multicolumn{4}{|l|}{ Proteobacteria } \\
\hline \multirow[t]{8}{*}{ Alphaproteobacteria } & Bartonella bacilliformis & СР000524 & $2(0.06)$ \\
\hline & Beijerinckia doebereinerae & NR116304 & $1(0.03)$ \\
\hline & Beijerinckia sp. & AB119205 & $1(0.03)$ \\
\hline & Bradyrhizobium canariense & KT880606 & $1(0.03)$ \\
\hline & Bradyrhizobium sp. & KP768784 & $2(0.06)$ \\
\hline & Jhaorihella thermophila & NR122093 & $1(0.03)$ \\
\hline & Methylobacterium aminovorans & HF570079 & $1(0.03)$ \\
\hline & Methylobacterium sp. & DQ341423 & $1(0.03)$ \\
\hline
\end{tabular}


TABLE 4. LIST OF BACTERIAL SPECIES IDENTIFIED FROM 12-YEAR- OLD OIL PALM PLANTATION AND AMPLIFIED USING PCR-DGGE METHOD, IN EACH CASE SHOWING THE SPECIES AND NCBI ACCESSION NUMBER OF THE CLOSEST MATCH IN THE GENBANK DATABASE (continued)

\begin{tabular}{|c|c|c|c|}
\hline Phylum class & Species & Accession no. & No. of species (\% of sp.) \\
\hline & Methylocapsa acidiphila & FN870340 & $1(0.03)$ \\
\hline & Methylocapsa palsarum & KP715289 & $1(0.03)$ \\
\hline & U. Methylocapsa sp. & KF581259 & $1(0.03)$ \\
\hline & Methylocystis sp. & FM252035 & $1(0.03)$ \\
\hline & Methylovirgula ligni & HG314007 & $2(0.06)$ \\
\hline & Ochrobactrum intermedium & СР013068 & $1(0.03)$ \\
\hline & Pannonibacter phragmitetus & LT625512 & $1(0.03)$ \\
\hline & U. Prosthecomicrobium sp. & FJ712836 & $1(0.03)$ \\
\hline & U. Rhizobium sp. & FM252035 & $1(0.03)$ \\
\hline & Rhizobium sp. & KF261556 & $4(0.13)$ \\
\hline & U. Rhodoplanes sp. & KP901801 & $1(0.03)$ \\
\hline & Rhodopseudomonas palustris & СР000301 & $1(0.03)$ \\
\hline & Shinella granuli & LN556390 & $6(0.19)$ \\
\hline & Shinella sp. & KJ676718 & $11(0.36)$ \\
\hline & Shinella zoogloeoides & KP979556 & $14(0.45)$ \\
\hline & U. Shinella sp. & KF115201 & $3(0.09)$ \\
\hline & U. Sphingomonas sp. & КС502959 & $1(0.03)$ \\
\hline & Rhizobiaceae bacterium & KM187074 & $1(0.03)$ \\
\hline & U. Alpha proteobacterium & LC017515 & $15(0.49)$ \\
\hline & U. Alphaproteobacteria bacterium & CU926981 & $12(0.39)$ \\
\hline & U. Beijerinckiaceae bacterium & KJ191883 & $1(0.03)$ \\
\hline & U. Hyphomicrobiaceae bacterium & EF663087 & $1(0.03)$ \\
\hline & U. Ensifer sp. & KF115604 & $1(0.03)$ \\
\hline & U. Methylocystaceae bacterium & KX366564 & $2(0.06)$ \\
\hline & U. Rhizobiales bacterium & JF814960 & $4(0.13)$ \\
\hline & U. type II methanotroph & KU234423 & $7(0.23)$ \\
\hline \multirow[t]{27}{*}{ Betaproteobacteria } & Alcaligenes faecalis & KP717562 & $1(0.03)$ \\
\hline & U. Burkholderia sp. & KP717562 & $8(0.26)$ \\
\hline & Burkholderia cepacia & HQ220017 & $2(0.06)$ \\
\hline & Burkholderia contaminans & KT719949 & $1(0.03)$ \\
\hline & Burkholderia mallei & СР009588 & $3(0.09)$ \\
\hline & Burkholderia pseudomallei & СР009271 & $9(0.29)$ \\
\hline & Burkholderia sp. & JQ994005 & $10(0.32)$ \\
\hline & Burkholderia thailandensis & СР004117 & $1(0.03)$ \\
\hline & Burkholderia vietnamiensis & HQ220010 & $1(0.03)$ \\
\hline & Candidatus Glomeribacter gigasporarum & AM889132 & $1(0.03)$ \\
\hline & Candidatus Zinderia insecticola & СP002161 & $1(0.03)$ \\
\hline & U. Collimonas sp. & JN590471 & $1(0.03)$ \\
\hline & Comamonas testosteroni & СР001220 & $5(0.16)$ \\
\hline & Janthinobacterium sp. & EU637885 & $1(0.03)$ \\
\hline & U. Janthinobacterium sp. & FN813705 & $1(0.03)$ \\
\hline & U. Neisseria sp. & EU629385 & $1(0.03)$ \\
\hline & U. Nitrosovibrio sp. & AM773618 & $1(0.03)$ \\
\hline & Pandoraea pulmonicola & CP010310 & $1(0.03)$ \\
\hline & Burkholderia caledonica & JN869243 & $1(0.03)$ \\
\hline & Burkholderia fungorum & GU182117 & $2(0.06)$ \\
\hline & Burkholderia tropica & AB568321 & $1(0.03)$ \\
\hline & Ralstonia insidiosa & LN890145 & $2(0.06)$ \\
\hline & Ralstonia solanacearum & FP885895 & $4(0.13)$ \\
\hline & Ralstonia sp. & KT949385 & $3(0.09)$ \\
\hline & U. Ralstonia sp. & EU705192 & $27(0.88)$ \\
\hline & U. Burkholderiales bacterium & СР015403 & $1(0.03)$ \\
\hline & U. beta proteobacterium & HF564040 & $28(0.91)$ \\
\hline
\end{tabular}


TABLE 4. LIST OF BACTERIAL SPECIES IDENTIFIED FROM 12-YEAR- OLD OIL PALM PLANTATION AND AMPLIFIED USING PCR-DGGE METHOD, IN EACH CASE SHOWING THE SPECIES AND NCBI ACCESSION NUMBER OF THE CLOSEST MATCH IN THE GENBANK DATABASE (continued)

\begin{tabular}{|c|c|c|c|}
\hline Phylum class & Species & Accession no. & No. of species (\% of sp.) \\
\hline \multirow{8}{*}{ Deltaproteobacteria } & U. Burkholderiaceae bacterium & EF562131 & $1(0.03)$ \\
\hline & U. Gallionellaceae bacterium & JQ177980 & $1(0.03)$ \\
\hline & U. Neisseriaceae bacterium & FM211965 & $1(0.03)$ \\
\hline & U. Rhodocyclaceae bacterium & HQ003476 & $1(0.03)$ \\
\hline & U. Desulfuromonas sp. & FN813680 & $1(0.03)$ \\
\hline & Bacteriovorax marinus & FQ312005 & $1(0.03)$ \\
\hline & U. delta proteobacterium & HE858114 & $2(0.06)$ \\
\hline & Ud. eubacterium & Y12374 & $2(0.06)$ \\
\hline Epsilonproteobacteria & Campylobacter concisus & СР000792 & $1(0.03)$ \\
\hline \multirow{21}{*}{ Gammaproteobacteria } & Campylobacter lari & СР007775 & $1(0.03)$ \\
\hline & Campylobacter hominis & СР000776 & $1(0.03)$ \\
\hline & Helicobacter pylori & EU019082 & $2(0.06)$ \\
\hline & U. Acinetobacter sp. & AM749861 & $1(0.03)$ \\
\hline & Candidatus Carsonella ruddii & $\mathrm{CP} 003542$ & $1(0.03)$ \\
\hline & Candidatus Portiera aleyrodidarum & LN649255 & $2(0.06)$ \\
\hline & Citrobacter koseri & СР000822 & $2(0.06)$ \\
\hline & Enterobacter hormaechei subsp. oharae & CP010384 & $2(0.06)$ \\
\hline & Enterobacter xiangfangensis & СР017183 & $1(0.03)$ \\
\hline & Escherichia albertii & AP014856 & $3(0.09)$ \\
\hline & Escherichia coli & LM997040 & $63(2.05)$ \\
\hline & Francisella cf. novicida & СР002558 & $1(0.03)$ \\
\hline & Haemophilus parasuis & CP009237 & $3(0.09)$ \\
\hline & Proteus sp. & JX105434 & $1(0.03)$ \\
\hline & U. Proteus sp. & JQ624310 & $1(0.03)$ \\
\hline & Pseudomonas fluorescens & СР003150 & $1(0.03)$ \\
\hline & Shigella sonnei & СР000038 & $3(0.09)$ \\
\hline & Pseudomonas hibiscicola & LC002978 & $1(0.03)$ \\
\hline & Tatlockia micdadei & LN614830 & $1(0.03)$ \\
\hline & U. proteobacterium & EF662552 & $14(0.45)$ \\
\hline & Xanthomonas campestris pv. campestris & EU089730 & $1(0.03)$ \\
\hline \multicolumn{4}{|l|}{ Spirochaetes } \\
\hline \multirow[t]{3}{*}{ Spirochaetia } & Brachyspira murdochii & СР001959 & $1(0.03)$ \\
\hline & Brachyspira pilosicoli & СР003490 & $1(0.03)$ \\
\hline & Spirochaeta thermophila & СР001698 & $1(0.03)$ \\
\hline \multicolumn{4}{|l|}{ Synergistetes } \\
\hline \multirow[t]{6}{*}{ Synergistia } & U. Cloacibacillus sp. & KT124624 & $5(0.16)$ \\
\hline & Cloacibacillus porcorum & LT223650 & $2(0.06)$ \\
\hline & Synergistes sp. & KU159767 & $2(0.06)$ \\
\hline & U. Synergistes sp. & KU355598 & $4(0.12)$ \\
\hline & U. Synergistaceae bacterium & KX672527 & $8(0.25)$ \\
\hline & U. Synergistetes bacterium & CU925037 & $6(0.19)$ \\
\hline \multicolumn{4}{|l|}{ Tenericutes } \\
\hline \multirow{4}{*}{ Mollicutes } & Mycoplasma arginini & AP014657 & $1(0.03)$ \\
\hline & Mycoplasma mycoides subsp. capri & KU870646 & $1(0.03)$ \\
\hline & Mycoplasma ovipneumoniae & KJ433280 & $3(0.09)$ \\
\hline & Spiroplasma turonicum & СР013860 & $1(0.03)$ \\
\hline \multicolumn{4}{|l|}{ Thermotogae } \\
\hline Thermotogae & Marinitoga piezophila & СР003257 & $1(0.03)$ \\
\hline Unclassified Archaea & U. archaeon & JQ792422 & $6(0.19)$ \\
\hline \multicolumn{4}{|l|}{ Unclassified Bacteria } \\
\hline & Bacterium enrichment culture & JX574952 & $6(0.19)$ \\
\hline & U. bacterium & AB672264 & $2103(68.35)$ \\
\hline & U. endolithic bacterium & AB374374 & $1(0.03)$ \\
\hline
\end{tabular}


TABLE 4. LIST OF BACTERIAL SPECIES IDENTIFIED FROM 12-YEAR- OLD OIL PALM PLANTATION AND AMPLIFIED USING PCR-DGGE METHOD, IN EACH CASE SHOWING THE SPECIES AND NCBI ACCESSION NUMBER OF THE CLOSEST MATCH IN THE GENBANK DATABASE (continued)

\begin{tabular}{|c|c|c|c|}
\hline Phylum class & Species & Accession no. & No. of species (\% of sp.) \\
\hline & U. forest soil bacterium & AY913265 & $6(0.19)$ \\
\hline & U. marine bacterium & FR685231 & $5(0.16)$ \\
\hline & U. methanotrophic bacterium & FN813709 & $1(0.03)$ \\
\hline & U. microorganism & KX925247 & $3(0.09)$ \\
\hline & U. prokaryote & КT043033 & $54(1.75)$ \\
\hline & U. rumen bacterium & LN612857 & $1(0.03)$ \\
\hline & U. soil bacterium & GQ918677 & $57(1.85)$ \\
\hline & Ud. marine bacterioplankton & KC002524 & $2(0.06)$ \\
\hline & Bacterial species (N) & \multicolumn{2}{|c|}{$3077(100)$} \\
\hline & Species richness & \multicolumn{2}{|c|}{195} \\
\hline & Shannon-wiener Index ( $\left.\mathrm{H}^{\prime}\right)$ & \multicolumn{2}{|c|}{$7.83 \pm 0.11$} \\
\hline
\end{tabular}

Note: U - uncultured; Ud - unidentified; NCBI - National Centre for Biotechnology Information; PCR-DDGE - polymerase chain reactiondenaturing gradient gel electrophoresis.

higher relative abundance in several soils and these bacteria are often difficult to cultivate.

Bacterial domains for phyla Actinobacteria, Bacteroidetes, Proteobacteria and Firmicutes were detected in both the culture-dependent and cultureindependent approaches, similar to previous studies which identified these bacterial groups using both approaches (Al-Awadhi et al., 2013; Chapman et al., 2017; González-Rocha et al., 2017). The present findings showed that these bacterial groups were in low abundances when detected using the culture-independent method but corresponded to the most abundant recovered phyla with the culture-dependent method. Even though these bacterial groups were detected in both methods, their compositions among the sampling sites varied which might be due to the specific matrix from the collected peat samples and different identification approaches (Al-Awadhi et al., 2013; González-Rocha et al., 2017). For instance, the majority of genera retrieved using the culture-independent method were unrecovered by the culture-dependent method, but interestingly $44 \%$ of those genera identified with the culturing method were not retrieved by the culture-independent method, illustrating that each approach has its own restrictions, intrinsic advantages and limitations in identifying bacterial taxonomy (González-Rocha et al., 2017). Meanwhile, $66 \%$ of genera were found in both methods. Similar to the present study, members of Actinobacteria, Bacteroidetes, Proteobacteria and Firmicutes were also identified with the culture-dependent methodology by Kusai and Ayob (2020).

The most abundant bacterial phylum, Proteobacteria, comprises of five classes, Alpha-, Beta- Delta-, Epsilon- and Gammaproteobacteria. According to the research of $\mathrm{Gu}$ et al. (2018), Alpha-, Beta- and Deltaproteobacteria were the highest in swamp soil compared to meadow and sandy soils, whilst Gammaproteobacteria was the highest in sandy soil. Within the Proteobacteria phylum, Betaproteobacteria was the abundant class that was identified using both approaches in the oil palm plantation ecosystems compared to other classes. In the present study, the genus Ralstonia (class Betaproteobacteria) was detected in both approaches and consisted of three species: $R$. insidiosa, $R$. solanacearum and Ralstonia sp. These findings were concordant with previous studies, which reported that these species were abundant and isolated from water, soil, and clinical samples (Ryan et al., 2006; Patton et al., 2009; Lim and Lee, 2017). Ralstonia possesses both chemoautotrophic and photoautotrophic properties and also plays a role in nitrogen fixation by oxidising ammonium to produce nitrite, making it available for various types of plants and benefitting the ecosystem (Lim and Lee, 2017).

Burkholderia (class Betaproteobacteria) was the second most abundant genus and was detected using both approaches. This genus is a nitrogenfixing, efficient mineral-weathering bacteria and also a decomposer in peat soils (Sun et al., 2014). In addition, Burkholderia sp. was previously reported as a molybdenum-reducing bacterium (Khayat et al., 2016) and glyphosate utilising bacteria (Manogaran et al., 2017) from contaminated soil. In the study by Nacke et al. (2014), Burkholderia and Bradyrhizobium, which are involved in lignin degradation and contain ligninolytic genes such as protocatechuate 3,4-dioxygenase and protocatechuate 4,5-dioxygenase homologues, were identified in forest and grassland soils by a pyrosequencingbased analysis of complementary DNA (cDNA). This suggests that these identified bacterial genera are involved in lignin degradation in peat swamp ecosystems and play a significant contribution to lignin breakdown (Nacke et al., 2014). 
Another major phylum in the oil palm plantation was Firmicutes (class Bacilli, Clostridia, Tissierella) which ranked among the 15 genera. Class Bacilli was detected predominantly using both approaches; this class has been reported to be abundant in tropical peat soils. These findings were in agreement with previous studies by Sun et al. (2014) and Tripathi et al. (2016), where the class was involved in the anaerobic degradation of soil organic carbon (Tripathi et al., 2018) and was suggested to be capable of withstanding high salinities and utilise uric acid under anaerobic conditions (Bottos et al., 2014). In addition, Firmicutes and Actinobacteria, which were enriched in the oil palm plantation soils, were associated with disease suppression (Wang et al., 2016). Actinobacteria has been shown to be copiotrophic and positively responds to carbon-rich environments (Shange et al., 2013). In addition, Actinobacteria is mainly linked to carbon cycling, is responsible for the breakdown of organic matter (Shange et al., 2013), and decomposes some recalcitrant carbon sources including cellulose and chitin ( $\mathrm{Li}$ et al., 2012). On the other hand, Acidobacteria was the second prevalent phylum detected using the culture-independent method and accounted for 9\%; six genera from this phylum were found in the total bacterial population of the oil palm plantation ecosystem. A previous study has reported that Acidobacteria plays important roles in peatland, such as in the degradation of cellulose and dead plant biomass, and also contributes to major nitrogen cycling in soils with their ability to reduce nitrate and nitrite (Tsitko et al., 2014). Besides that, the phylum Synergistetes accounted for $1 \%$ of the total population detected using the culture-independent method. These bacteria possess the ability to degrade amino acids and are known as amino-acid degrading bacteria, and have been previously studied by Honda et al. (2013) in Japanese rice soil fields.

Among the members of Bacteroidetes, the genera Flavobacterium and Chryseobacterium were less abundant in the oil palm plantation and have been reported to play a role in promoting plant growth (Soltani et al., 2010; Nishioka et al., 2016) and cellulose decomposition in topsoil (Sun et al., 2014; Mendes et al., 2015). In addition, the genus Flavobacterium is responsible for heterotrophic denitrification (Wang et al., 2016). The fact that oil palm soils have less exposure to sunlight due to oil palm frond cover is reflected in the lower relative abundances of photosynthesis-related bacterial phyla such as Cyanobacteria, Chloroflexi and Chlorobi (Tripathi et al., 2018). In addition, the results were in agreement with previous observations that the phylum Chloroflexi was found in the oil palm and rubber plantations, and forest soils (Mendes et al., 2015; Kerfahi et al., 2016; Tripathi et al., 2016; Grodnitskaya et al., 2018). Chloroflexi has also been reported to prevail in nutrient-poor soils, confirming their oligotrophic characteristics (Ding et al., 2013).

On the other hand, the least abundant domain in the present study, Archaea, was affiliated to the Crenarchaeota, Euryarchaeota and unclassified Archaea, and was found in samples taken from the peat surface down to $30 \mathrm{~cm}$. It was consistent with Jackson et al. (2009), who stated that the incidence of archaea communities was higher with increasing depth, which might be because the anoxic conditions in deeper peat facilitated the growth of methanogenic Euryarchaeota. The present study showed that oil palm plantations or agricultural use impacted several bacterial phyla in peat soils, even though less abundance was recorded by the culture-independent method, i.e., Candidatus Cloacimonetes, Deinococcus-Thermus, Dictyoglomi, Spirochaetes, Tenericutes and Thermotogae. These bacterial groups were detected using the cultureindependent method, but none was detected by the culture-dependent method. DeinococcusThermus was identified by the culture-independent method using PCR-DGGE analysis; however, it was contradictory to a previous study by Ellis et al. (2003), who identified these species with the culturedependent method using a fatty acid methyl ester (FAME) analysis. This result was in accordance with a previously published study, which reported phylum Deinococcus-Thermus had a positive association with the $\mathrm{Cu}, \mathrm{Zn}$ and nickel (Ni) present in the mine environments samples (Pereira et al., 2014).

\section{CONCLUSION}

These results showed that the culture-independent approach could reveal higher richness and diversity compared to culture-dependent method. It could be concluded that PCR-DGGE method was more efficient to identify the low-abundance and difficultto-culture prokaryotic taxa including Acidobacteria, Archaea and Unclassified Bacteria, which were not detected by culture-dependent method and more novel bacterial communities in the peat soil still have not been reported by other researchers. Taken together, these observations suggest further investigation, i.e., using next-generation sequencing in elucidating the community functions and their impact on agriculture land management practices, specifically on bacterial communities in Southeast Asia peatlands.

\section{ACKNOWLEDGEMENT}

The authors would like to thank the Director-General of MPOB for the permission to publish this article. This work was supported by MPOB Research Board under Grant R009711000. 


\section{REFERENCES}

Abedon, S T (2011). Communication among phages, bacteria, and soil environments. Biocommunication in Soil Microorganisms (Witzany, G ed.). Springer, Berlin, Heidelberg. p. 37-65.

Al-Awadhi, H; Dashti, N; Khanafer, M; Al-Mailem, D; Ali, N and Radwan, S (2013). Bias problems in culture-independent analysis of environmental bacterial communities: A representative study on hydrocarbonoclastic bacteria. SpringerPlus, 2(1): 1-11.

Arai, H; Hadi, A; Darung, U; Limin, S H; Hatano, $\mathrm{R}$ and Inubushi, K (2014). A methanotrophic community in a tropical peatland is unaffected by drainage and forest fires in a tropical peat soil. Soil Science and Plant Nutrition, 60(4): 577-585.

Ayob, Z; Kusai, N A and Ali, S R A (2018). Sequence-based identification and characterisation of cultivated filamentous fungi in the Alan Bunga peat ecosystems of Sarawak, Malaysia. Mires Peat, 21(16): 1-19.

Bah, A R and Rahman, Z A (2004). Evaluating urea fertilizer formulations for oil palm seedlings using the $15 \mathrm{~N}$ isotope dilution technique. J. Oil Palm Res. Vol. 16(1): 72-77.

Bottos, E M; Scarrow, J W; Archer, S D J; Mcdonald, I R and Cary, S C (2014). Bacterial community structures of Antarctic soils. Antarctic Terrestrial Microbiology (Cowan, D A ed.). Springer, Berlin, Heidelberg. p. 9-33.

Chapman, E J; Cadillo-Quiroz, H; Childers, D L; Turetsky, M R and Waldrop, M P (2017). Soil microbial community composition is correlated to soil carbon processing along a boreal wetland formation gradient. Eur. J. Soil Biol., 82: 17-26.

Chen, H-C; Wang, S-Y and Chen, M-J (2008). Microbiological study of lactic acid bacteria in kefir grains by culture-dependent and cultureindependent methods. Food Microbiol., 25(3): 492501.

Chaudhary, D K; Khulan, A and Kim, J (2019). Development of a novel cultivation technique for uncultured soil bacteria. Scientific Reports, 9(1): 1-11.

Dashti, A A; Jadaon, M M; Abdulsamad, A M and Dashti, H M (2009). Heat treatment of bacteria: A simple method of DNA extraction for molecular techniques. Kuwait Med. J., 41(2): 117-122.

Davis, K E R; Joseph, S J and Janssen, P H (2005). Effects of growth medium, inoculum size, and incubation time on culturability and isolation of soil bacteria. Applied and Environmental Microbiology, 71(2): 826-834.

Dhandapani, S; Ritz, K; Evers, S and Sjögersten, S (2019). Environmental impacts as affected by different oil palm cropping systems in tropical peatlands. Agriculture, Ecosystems and Environment, 276: 8-20.

Ding, G-C; Piceno, Y M; Heuer, H; Weinert, N; Dohrmann, A B; Carrillo, A; Andersen, G L; Castellanos, T; Tebbe, C C and Smalla, K (2013). Changes of soil bacterial diversity as a consequence of agricultural land use in a semi-arid ecosystem. PLOS ONE, 8(3): 1-10.

Edenborn, S L and Sexstone, A J (2007). DGGE fingerprinting of culturable soil bacterial communities complements culture-independent analyses. Soil Biol. Biochem., 39(7): 1570-1579.

El Karkouri, A; Assou, S A and El Hassouni, M (2019). Isolation and screening of actinomycetes producing antimicrobial substances from an extreme Moroccan biotope. Pan African Medical J., 33: $1-9$.

Ellis, R J; Morgan, P; Weightman, A J and Fry, J C (2003). Cultivation-dependent and-independent approaches for determining bacterial diversity in heavy-metal-contaminated soil. Appl. Environ. Microbiol., 69(6): 3223-3230.

Fierer, N; Bradford, M A A and Jackson, R B B (2007). Toward an ecological classification of soil bacteria. Ecology, 88(6): 1354-1364.

Fierer, N and Jackson, R B (2006). The diversity and biogeography of soil bacterial communities. PNAS, 103(3): 626-631.

Fuhrman, J A; Cram, J A and Needham, D M (2015). Marine microbial community dynamics and their ecological interpretation. Nat. Rev. Microbiol., 13(3): 133-146.

Germida, J J and de Freitas, J R (2007). Cultural methods for soil and root-associated microorganisms. Soil Sampling and Methods of Analysis, Second Edition (Cater, M R and Gregorich, E G eds.). CRC Press, Boca Raton. p. 371-383.

Ghazali, N N; Adilah, M M M K; Abidin, Z A Z and Omar, S M (2016). Comparison of various culture media effectiveness in the isolation of bacteria from Pekan peat swamp forest soil. Malaysian J. Microbiology, 12(6): 450-454. 
González-Rocha, G; Muñoz-Cartes, G; CanalesAguirre, C B; Lima, C A; Domínguez-Yévenes, M; Bello-Toledo, H and Hernández, C E (2017). Diversity structure of culturable bacteria isolated from the Fildes Peninsula (King George Island, Antarctica): A phylogenetic analysis perspective. PLoS ONE, 12(6): 1-18.

Green, S J; Leigh, M B and Neufeld, J D (2010). Denaturing gradient gel electrophoresis (DGGE) for microbial community analysis. Handbook of Hydrocarbon and Lipid Microbiology (Timmis, K N ed.). Springer-Verlag, Berlin, Heidelberg. p. 41374158.

Grodnitskaya, I D; Trusova, M Y; Syrtsov, S N and Koroban, N V (2018). Structure of microbial communities of peat soils in two bogs in Siberian tundra and forest zones. Microbiology, 87(1): 89-102.

Gu, Y; Bai, Y; Xiang, Q; Yu, X; Zhao, K; Zhang, X; Li, C; Liu, S and Chen, Q (2018). Degradation shaped bacterial and archaeal communities with predictable taxa and their association patterns in Zoige wetland at Tibet plateau. Sci. Rep., 8(1): 1-11.

Hill, M O (1973). Diversity and evenness: A unifying notation and its consequences. Ecology, 54(2): 427432.

Holland, K T (1987). Anaerobic Bacteria. Springer, USA.

Honda, T; Fujita, T and Tonouchi, A (2013). Aminivibrio pyruvatiphilus gen. nov., sp. nov., an anaerobic, amino-acid-degrading bacterium from soil of a Japanese rice field. Int. J. Syst. Evol. Microbiol., 63(Pt 10): 3679-3686.

Hu, X; Chen, J and Guo, J (2006). Two phosphateand potassium-solubilizing bacteria isolated from Tianmu Mountain, Zhejiang, China. World J. Microbiology and Biotechnology, 22(9): 983-990.

Jackson, C R; Liew, K C and Yule, C M (2009). Structural and functional changes with depth in microbial communities in a tropical Malaysian peat swamp forest. Microbial Ecology, 57(3): 402-412.

Jianzhong, Z; Xiaoli, L; Hanhu, J and Mingsheng, D (2009). Analysis of the microflora in Tibetan kefir grains using denaturing gradient gel electrophoresis. Food Microbiol., 26(8): 770-775.

Kanokratana, P; Uengwetwanit, T; Rattanachomsri, U;Bunterngsook, B;Nimchua,T; Tangphatsornruang, S; Plengvidhya, V; Champreda, V and Eurwilaichitr, L (2011). Insights into the phylogeny and metabolic potential of a primary tropical peat swamp forest microbial community by metagenomic analysis. Microbial Ecology, 61(3): 518-528.

Kerfahi, D; Tripathi, B M; Dong, K; Go, R and Adams, J M (2016). Rainforest conversion to rubber plantation may not result in lower soil diversity of bacteria, fungi, and nematodes. Microb. Ecol., 72(2): 359-371.

Kerfahi, D; Tripathi, B M; Lee, J; Edwards, D P and Adams, J M (2014). The impact of selectivelogging and forest clearance for oil palm on fungal communities in Borneo. PLoS ONE, 9(11): 1-8.

Kesmen, Z and Kacmaz, N (2011). Determination of lactic microflora of kefir grains and kefir beverage by using culture-dependent and culture-independent methods. J. Food Sci., 76(5): 276-283.

Khayat, M E; Abd Rahman, M F; Shukor, M S; Ahmad, S A; Shamaan, N A and Shukor, M Y (2016). Characterization of a molybdenum-reducing Bacillus sp. strain khayat with the ability to grow on SDS and diesel. Rend. Fis. Acc. Lincei, 27(3): 547-556.

Kusai, N A and Ayob, Z (2020). Bacterial diversity in peat soils of forest ecosystems and oil palm plantation. Eurasian Soil Science, 53(4): 485-493.

Kusai, N A; Ayob, Z; Maidin, M S T; Safari, S and Ali, S R A (2018). Characterization of fungi from different ecosystems of tropical peat in Sarawak, Malaysia. Rend. Fis. Acc. Lincei, 29(2): 469-482.

Li, R; Khafipour, E; Krause, DO; Entz, MH; de Kievit, T R and Fernando, W G D (2012). Pyrosequencing reveals the influence of organic and conventional farming systems on bacterial communities. PLoS ONE, 7(12): 1-12.

Lim, C T S and Lee, SE (2017). A rare case of Ralstonia mannitolilytica infection in an end stage renal patient on maintenance dialysis during municipal water contamination. Pak. J. Med. Sci., 33(4): 1047-1049.

Lipson, D A and Schmidt, S K (2004). Seasonal changes in an alpine soil bacterial community in the Colorado Rocky Mountains. Appl. Environ. Microbiol., 70(5): 2867-2879.

Liu, B; Talukder, M J H; Terhonen, E; Lampela, M; Vasander, H; Sun, H and Asiegbu, F (2020). The microbial diversity and structure in peatland forest in Indonesia. Soil Use and Management, 36(1): 123138.

Maidin, M S T; Safari, S; Ghani, N A; Ibrahim, S A S; Bakeri, S A; Masri, M M M and Ali, S R A (2016). Differences in prokaryotic species between primary 
and logged-over deep Peat forest in Sarawak, Malaysia. J. Oil Palm Res. Vol. 28(3): 281-295.

Manogaran, M; Shukor, M Y; Yasid, N A; Wan Johari, W L and Ahmad, S A (2017). Isolation and characterisation of glyphosate-degrading bacteria isolated from local soils in Malaysia. Rend. Fis. Acc. Lincei, 28(3): 471-479.

Melling, L (2016). Peatland in Malaysia. Tropical Peatland Ecosystems (Osaki, M and Tsuji, N eds.). Springer, Tokyo. p. 59-73.

Mendes, L W; Tsai, S M; Navarrete, A A; De Hollander, M; Van Veen, J A and Kuramae, E E (2015). Soil-borne microbiome: Linking diversity to function. Microb. Ecol., 70(1): 255-265.

Miguel, M G da C P; Cardoso, P G; Lago, L de A and Schwan, R F (2010). Diversity of bacteria present in milk kefir grains using culture-dependent and culture-independent methods. Food Res. Int., 43(5): 1523-1528.

Muyzer, G; Teske, A; Wirsen, CO and Jannasch, H W (1995). Phylogenetic relationships of Thiomicrospira species and their identification in deep-sea hydrothermal vent samples by denaturing gradient gel-electrophoresis of $16 \mathrm{~S}$ rDNA fragments. Arch. Microbiol, 164(3): 165-172.

Muyzer, G; De Waal, E C and Uitterlinden, A G (1993). Profiling of complex microbial populations by denaturing gradient gel electrophoresis analysis of polymerase chain reaction-amplified genes coding for 16S rRNA. Appl. Environ. Microbiol., 59(3): 695-700.

Nacke, H; Fischer, C; Thürmer, A; Meinicke, P and Daniel, R (2014). Land use type significantly affects microbial gene transcription in soil. Microb. Ecol., 67(4): 919-930.

Nagendran, A N; Deivendran, S and Prabavathi, S (2014). Diversity of soil microbes under different ecosystem landuse patterns. J. Applied and Environmental Microbiology, 2(4): 90-96.

Nath, S; Deb, B and Sharma, I (2018). Isolation of toxic metal-tolerant bacteria from soil and examination of their bioaugmentation potentiality by pot studies in cadmium- and lead-contaminated soil. International Microbiology, 21(1-2): 35-45.

Nishioka, T; Elsharkawy, M M; Suga, H; Kageyama, K; Hyakumachi, $\mathrm{M}$ and Shimizu, M (2016). Development of culture medium for the isolation of Flavobacterium and Chryseobacterium from rhizosphere soil. Microbes Environ., 31(2): 104-110.
Nurulita, Y; Adetutu, E M; Kadali, K K; Shahsavari, E; Zul, D; Taha, M and Ball, A S (2016). Assessment of the influence of oil palm and rubber plantations in tropical peat swamp soils using microbial diversity and activity analysis. J. Agric. Chem. Environ., 5: 53-65.

Olsen, R A and Bakken, L R (1987). Viability of soil bacteria: Optimization of plate-counting technique and comparison between total counts and plate counts within different size groups. Microb. Ecol., 13(1): 59-74.

Page, S E and Baird, A J (2016). Peatlands and global change: Response and resilience. Annu. Rev. Environ. Resour., 41(1): 35-57.

Pallant, J (2007). SPSS Survival Manual. McGraw Hill Open University Press, New York, USA.

Pankratov, T A; Serkebaeva, Y M; Kulichevskaya, I S; Liesack, W and Dedysh, S N (2008). Substrateinduced growth and isolation of Acidobacteria from acidic Sphagnum peat. ISME J., 2(5): 551-560.

Paramananthan, S (2016). Organic Soils of Malaysia: Their Characteristics, Mapping, Classification and Management for Oil Palm Cultivation. Malaysian Palm Oil Council, Selangor, Malaysia.

Parish, F; Lim, S S; Perumal, B and Giesen, W (2012). RSPO Manual on best management practices (BMPs) for management and rehabilitation of natural vegetation associated with oil palm cultivation on peat. Roundtable on Sustainable Palm Oil (RSPO), Kuala Lumpur.

Patton, T G; Scupham, A J; Bearson, S M D and Carlson, S A (2009). Characterization of fecal microbiota from a Salmonella endemic cattle herd as determined by oligonucleotide fingerprinting of rDNA genes. Vet. Microbiol., 136(3-4): 285-292.

Pereira, L B; Vicentini, R and Ottoboni, L M M (2014). Changes in the bacterial community of soil from a neutral mine drainage channel. PLoS ONE, 9(5): 1-10.

Piterina, A V and Pembroke, J T (2013). Use of PCR-DGGE based molecular methods to analyse microbial community diversity and stability during the thermophilic stages of an ATAD wastewater sludge treatment process as an aid to performance monitoring. International Scholarly Research Notices, Vol. 2013: 1-13.

Porter, J N; Wilhelm, J J and Tresner, H D (1960). Method for the preferential isolation of Actinomycetes from soils. Applied Microbiology, 8: 174-178. 
Posa, M R C; Wijedasa, L S and Corlett, R T (2011). Biodiversity and conservation of tropical peat swamp forests. BioScience, 61(1): 49-57.

Qaisrani, M M; Zaheer, A; Mirza, M S; Naqqash, T; Qaisrani, T B; Hanif, M K; Rasool, G; Malik, K A; Ullah, S; Jamal, M S; Mirza, Z; Karim, S and Rasool, $M$ (2019). A comparative study of bacterial diversity based on culturable and culture-independent techniques in the rhizosphere of maize (Zea mays L.). Saudi J. Biological Sciences, 26(7): 1344-1351.

Rennie, R J (1981). A single medium for the isolation of acetylene-reducing (dinitrogen-fixing) bacteria from soils. Canadian J. Microbiology, 27(1): 8-14.

Roslan, M A M; Amirudin, N A; Abidin, Z A Z and Omar, S M (2015). Isolation of bacteria from the acidic peat swamp forest soil and their lignin degradation potential. Jurnal Teknologi, 77(24): 77-81.

Ruangsanka, S (2014). Identification of phosphatesolubilizing bacteria from the bamboo rhizosphere. ScienceAsia, 40(3): 204-211.

Ryan, M P; Pembroke, J T and Adley, C C (2006). Ralstonia pickettii: A persistent Gram-negative nosocomial infectious organism. J. Hosp Infect., 62(3): 278-284.

Schneider, D; Engelhaupt, M; Allen, K; Kurniawan, S; Krashevska, V; Heinemann, M; Nacke, H; Wijayanti, M; Meryandini, A; Corre, M D; Scheu, S and Daniel, R (2015). Impact of lowland rainforest transformation on diversity and composition of soil prokaryotic communities in Sumatra (Indonesia). Front. Microbiol., 6: 1-12.

Shade, A; Hogan, C S; Klimowicz, A K; Linske, M; Mcmanus, PS and Handelsman, J (2012). Culturing captures members of the soil rare biosphere. Environ. Microbiol., 14(9): 2247-2252.

Shange, R; Haugabrooks, E; Ankumah, R; Ibekwe, A M; Smith, R C and Dowd, S (2013). Assessing the diversity and composition of bacterial communities across a wetland, transition, upland gradient in Macon County Alabama. Diversity, 5(3): 461-478.

Shannon, C E and Weaver, W (1949). The Mathematical Theory of Communication. University of Illinois Press, Urbana, Illinois.

Sheil, D; Casson, A; Meijaard, E; van Noordwjik, M; Gaskel, J; Sunderland-Groves, J; Wertz, K and Kanninen, M (2009). The impacts and opportunities of oil palm in Southeast Asia: What do we know and what do we need to know? Centre for International Forestry Research (CIFOR). Bogor, Indonesia. 67 pp.
Singh, P; Raghukumar, C; Verma, P and Shouche, Y (2012). Assessment of fungal diversity in deep-sea sediments by multiple primer approach. World J. Microbiol Biotechnol., 28(2): 659-667.

Singh, S S; Schloter, M; Tiwari, S C and Dkhar, M S (2011). Diversity of community soil DNA and bacteria in degraded and undegraded tropical forest soils of North-eastern India as measured by ERICPCR fingerprints and 165 rDNA-DGGE profiles. J. Biol. Environ. Sci., 5(15): 183-194.

Situmorang, E C; Nugroho, Y A; Prameswara, A; Andarini, E; Hartono, Setyobudi, R H; ToruanMathius, $\mathrm{N}$ and Liwang, $\mathrm{T}$ (2016). The bacterial diversity investigation in oil palm plantation using terminal restriction length polymorphism. AIP Conference Proceedings, 1744: 020017-1-020017-9.

Smit, E; Leeflang, P; Gommans, S; Van Den Broek, J; Van Mil, S and Wernars, K (2001). Diversity and seasonal fluctuations of the dominant members of the bacterial soil community in a wheat field as determined by cultivation and molecular methods. Appl. Environ. Microbiol., 67(5): 2284-2291.

Soltani, A-A; Khavazi, K; Asadi-Rahmani, H; Omidvari, M; Dahaji, P A and Mirhoseyni, H (2010). Plant growth promoting characteristics in some Flavobacterium spp. isolated from soils of Iran. J. Agric. Sci., 2(4): 106-115.

Stewart, E J (2012). Growing unculturable bacteria. J. Bacteriol., 194(16): 4151-4160.

Sun, H; Terhonen, E; Koskinen, K; Paulin, L; Kasanen, R and Asiegbu, F O (2014). Bacterial diversity and community structure along different peat soils in boreal forest. Appl. Soil Ecol., 74: 37-45.

Sutton, S (2011). Accuracy of plate counts. J. Valid. Technol., 17(3): 42-46.

Teo, J K C and Wong, C M V L (2014). Analyses of soil bacterial diversity of the Schirmacher Oasis, Antarctica. Polar Biol., 37(5): 631-640.

Too, C C; Keller, A; Sickel, W; Lee, S M and Yule, C M (2018). Microbial community structure in a Malaysian tropical peat swamp forest: The influence of tree species and depth. Front Microbiol., 9: 1-13.

Tripathi, B M; Kim, M; Kim, Y; Byun, E; Yang, J-W; Ahn, J and Lee, Y K (2018). Variations in bacterial and archaeal communities along depth profiles of Alaskan soil cores. Sci. Rep., 8(1): 1-11.

Tripathi, B M; Song, W; Slik, J W F; Sukri, R S; Jaafar, S; Dong, K and Adams, J M (2016). Distinctive 
tropical forest variants have unique soil microbial communities, but not always low microbial diversity. Front Microbiol., 7: 1-11.

Troxler, T G; Ikenaga, M; Scinto, L; Boyer, J N; Condit, R; Perez, R; Gann, G D and Childers, D L (2012). Patterns of soil bacteria and canopy community structure related to tropical peatland development. Wetlands, 32(4): 769-782.

Tsitko, I; Lusa, M; Lehto, J; Parviainen, L; Ikonen, A T K; Lahdenperä, A-M and Malin, B (2014). The variation of microbial communities in a depth profile of an acidic, nutrient-poor boreal bog in Southwestern Finland. Open J. Ecol., 4(13): 832-859.

Vazquez, P; Holguin, G; Puente, M E; Lopez-Cortes, A and Bashan, Y (2000). Phosphate-solubilizing microorganisms associated with the rhizosphere of mangroves in a semiarid coastal lagoon. Biology and Fertility of Soils, 30(5-6): 460-468.

Veloo, R; Ranst, E van and Selliah, P (2015). Peat characteristics and its impact on oil palm yield. NJAS Wagen J. Life Sc., 72-73: 33-40.
Vincent, W F (2000). Evolutionary origins of Antarctic microbiota: Invasion, selection and endemism. Antarct. Sci., 12(3): 374-385.

Wang, W; Wang, H; Feng, Y; Wang, L; Xiao, X; Xi, Y; Luo, X; Sun, R; Ye, X; Huang, Y; Zhang, Z and Cui, Z (2016). Consistent responses of the microbial community structure to organic farming along the middle and lower reaches of the Yangtze River. Sci. Rep., 6: 1-11.

Watanabe, T; Asakawa, S; Nakamura, A; Nagaoka, K and Kimura, M (2004). DGGE method for analyzing $16 \mathrm{~S}$ rDNA of methanogenic archaeal community in paddy field soil. FEMS Microbiology Letters, 232(2): 153-163.

Wu, Z; Lin, W; Li, B; Wu, L; Fang, C and Zhang, $Z$ (2015). Terminal restriction fragment length polymorphism analysis of soil bacterial communities under different vegetation types in subtropical area. PLOS ONE, 10(6): 1-10. 